\title{
Comparative Study on Performance of Renewable Energy Building Energy Supply System
}

\author{
Jiang Xiufang ${ }^{1}$, Diao Rongdan ${ }^{1, *}$, Zeng $\mathrm{Li}^{2, *}$, Zhang Ying ${ }^{1}$ and Lei Xinrong ${ }^{1}$ \\ ${ }^{1}$ College of Civil Engineering and Architecture, Wenzhou University, Wenzhou 325035, China \\ ${ }^{2}$ WenZhou JianZheng Energy Technology Co., Ltd, Wenzhou 325035, Zhejiang, China
}

\begin{abstract}
The air source heat pump water system test bench and the compact all-glass vacuum tube solar water heating system test bench are (were) built on the roof of two adjacent teacher's apartment buildings with the same structure, shape and material were constructed to study the performance of energy supply systems for different types of renewable energy buildings. The energy supply system performance and the performance parameters are comprehensively and systematically analyzed in the same environment conditions of the same period. The results show that the weight coefficients of the performance parameters of the two energy supply systems are equal by means of extension theory analysis. At the last, the comprehensive correlation degree $\mathrm{Kj}(1)$ of water outlet temperature on the performance of renewable energy power supply system is 2.07 , the comprehensive correlation degree $\mathrm{Kj}(2)$ of water inlet temperature is 2.04 , the comprehensive correlation degree $\mathrm{Kj}(3)$ of air temperature is 2.14 , the comprehensive correlation degree $\mathrm{Kj}(4)$ of solar radiation is 4.97 , and the comprehensive correlation degree $\mathrm{Kj}(5)$ of sunshine hours is 3.78 .
\end{abstract}

\section{Introduction}

The building energy consumption in China increased by $37 \%$ from 2000 to 2012. By 2050, the total energy consumption of buildings will increase by $70 \%{ }^{[1,2]}$ than that in 2012. In recent years, renewable energy buildings have occupied a large proportion of the application market ${ }^{[3,4]}$.

At present, scholars at home and abroad have carried out a series of research on renewable energy supply system. Lu Yuexia [5-7] has studied the economic performance of residential roof solar water heating system; Truong N L ${ }^{[8-10]}$ research shows that the overall performance of the system is particularly important; Poppi ${ }^{[11,12]}$ study shows that the impact of electricity price changes on solar air source heat pump system is far more than other economic parameters. Cai ${ }^{[13]}$ and other studies show that the heat pump COP increases with the increase of solar irradiance. Wang Jian ${ }^{[14,15]}$ has studied the optimization and performance of the centralized solar water heating system; And Ke Guangyao [16] has evaluated the flow and heat transfer performance of the solar water heating system at different initial temperatures. However, different kinds of renewable energy buildings are not placed under the same test conditions, making the system performance comparable. The performance and performance parameters of different energy supply systems are compared and analyzed.

In view of the above problems, this article refers to the GB/T 50801-2013"Evaluation standard for application of renewable energy in buildings" [17] in the two buildings with the adjacent structure, the same type of structure, the same type of material and the same building as the roof of the teachers' apartment building respectively to build the air source heat pump hot water system and the compact full glass vacuum tube hot water system test bench. The two sets of test devices are placed in the same test environment to perform the performance test of the same cycle system. The system performance and performance parameters of the energy supply system are analyzed, and the weight coefficient of the system performance influence parameters is analyzed by extension theory, and the comprehensive correlation degree of the performance parameters of the renewable energy supply system is calculated.

\section{Introduction of pilot projects}

This project takes two adjacent Teacher's apartment buildings with the same structure, shape and material as the research object. As shown in Figure 1, the number of apartment buildings is 11 floors, with 6 households on each floor. The apartment is one bedroom, one hall, one balcony and one balcony. The building area is $29.2 \mathrm{~m}^{2}$. In order to improve accommodation conditions and facilitate the use of hot water for teachers, a compact full glass evacuated tube hot water system and an air source heat pump hot water system were installed on the top of two apartment buildings to provide 24 hours of hot water for households. 


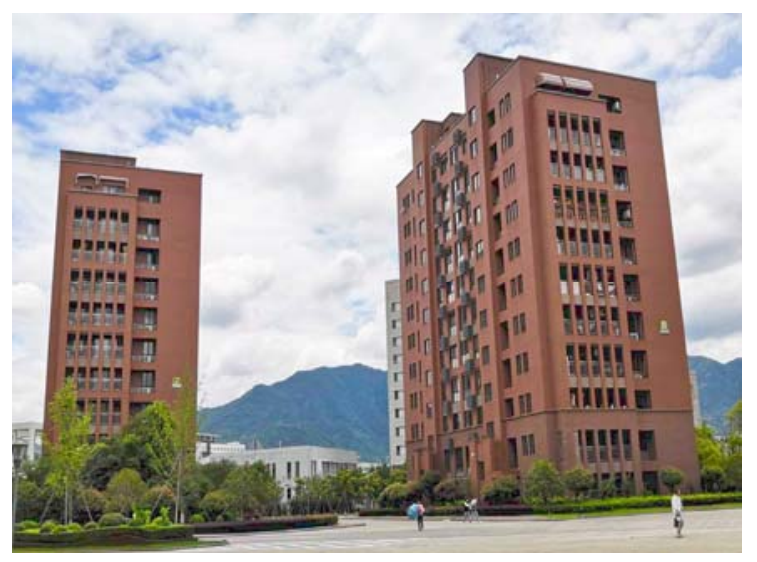

Figure 1. Experimental Teacher Apartment Building

\section{Test equipment}

The YG-QXZ-350 automatic weather station is used to conduct real-time monitoring of meteorological data in the test environment, including wind speed, temperature, solar radiation and sunshine hours. The data acquisition cycle is 10 min times $^{-1}$. The automatic weather station is placed on the roof of the experimental apartment building, the location is $1.2 \mathrm{~m}$ above the ground level, and the distance from the energy supply system is $2 \mathrm{~m}$. There are no chimneys, cooling towers or hot air exhausting fans. Comply with the requirements of GB/T 18708-2002 "Test methods for thermal performance of domestic solar water heating systems " [18].

During the test, the renewable energy system uses the intelligent management system of the water heater to collect all the data of the unit, including water meter reading, meter reading, water consumption, electricity consumption, water supplement, energy consumption ratio, heat generation and heating time. It can set the switchgear and heating temperature through the parameters, and upload data to the platform every $2 \mathrm{~min}$ by GPRS, and transmit the platform to the control cabinet in real time. The relay uses $220 \mathrm{~V}$ electrical signals to control water supply, replenishment and backwater.

In the renewable energy supply system, the vacuum tube solar water heating system consists of 18 groups, the specifications are 36 branch pipes, the vacuum tube size is $\Phi 58 \mathrm{~mm} * 1800 \mathrm{~mm}$, the daylight area is $4.46 \mathrm{~m} 2$, the size of the air source heat pump water heating system is $800 \mathrm{~mm} \times 800 \mathrm{~mm} \times 1105 \mathrm{~mm}$, the specific technical parameters of the solar water heating system and the air source heat pump hot water system are shown in Table 1, and the test equipment is shown in Figure 2.

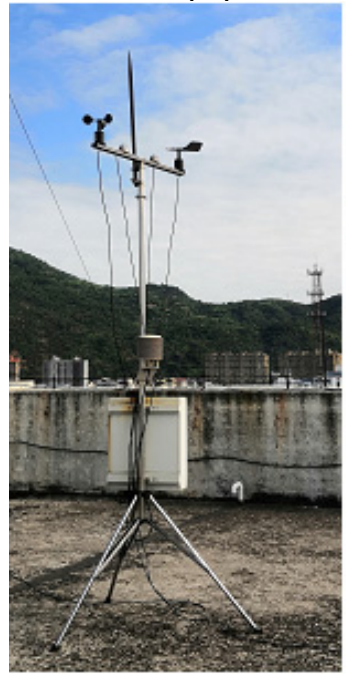

Automatic weather station

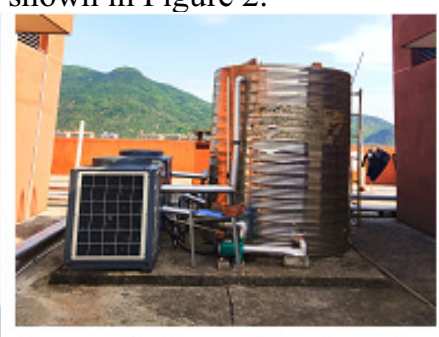

Air source heat pump hot water system

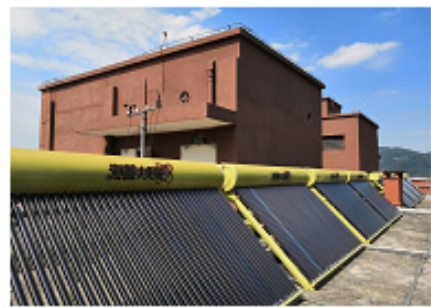

Vacuum tube solar hot water system
Figure 2. Test Equipment

Table 1.Parameters of Renewable Energy Supply System

\begin{tabular}{|c|c|c|c|}
\hline Name & Model & function & Other parameters \\
\hline $\begin{array}{c}\text { Air source heat pump hot water } \\
\text { system }\end{array}$ & KFXRS-18II & $\begin{array}{l}\text { Heating test circulating } \\
\text { water }\end{array}$ & $\begin{array}{l}\text { Water yield: } 400 \mathrm{~L} \cdot \mathrm{h}^{-1} \\
\text { Rated input power: } 4280 \mathrm{w} \\
\text { COP: } 4.44 \\
\text { Rated effluent temperature: } 55^{\circ} \mathrm{C} \\
\text { Rated circulating water flow rate: } 3.0 \mathrm{~m}^{3} \cdot \mathrm{h}^{-1}\end{array}$ \\
\hline $\begin{array}{l}\text { Vacuum tube solar water } \\
\text { heating system }\end{array}$ & $\begin{array}{l}36 \text { branch pipe: } \\
\Phi 58 \mathrm{~mm} * 1800 \mathrm{~mm}\end{array}$ & $\begin{array}{l}\text { Heating test circulating } \\
\text { water }\end{array}$ & Water consumption: $360 \mathrm{~L}$ \\
\hline Wind speed sensor & YGC-FS & Wind speed measurement & $\begin{array}{l}\text { Measurement range: } 0 \sim 70 \mathrm{~m} \cdot \mathrm{s}^{-1} \\
\text { Resolution: } 0.1 \mathrm{~m} \cdot \mathrm{s}^{-1} \\
\text { Accuracy: } \pm(0.3 \pm 0.03 \mathrm{~V}) \mathrm{m} \cdot \mathrm{s}^{-1}\end{array}$ \\
\hline Air temperature sensor & YGC-QW & $\begin{array}{l}\text { Air temperature } \\
\text { measurement }\end{array}$ & $\begin{array}{l}\text { Measurement range: }-50 \sim 100{ }^{\circ} \mathrm{C} \\
\text { Resolution: } 0.1{ }^{\circ} \mathrm{C} \\
\text { Accuracy: } \pm 0.3{ }^{\circ} \mathrm{C}\end{array}$ \\
\hline Air relative humidity sensor & YGC-QS & $\begin{array}{c}\text { Measuring relative humidity } \\
\text { of air }\end{array}$ & $\begin{array}{l}\text { Measurement range: } 0 \sim 100 \% \mathrm{RH} \\
\text { Resolution: } 0.1 \% \mathrm{RH} \\
\text { Accuracy: } \pm 3 \%\end{array}$ \\
\hline Solar radiation meter & YGC-TBQ & Measuring solar radiation & $\begin{array}{l}\text { Measurement range: } 0 \sim 2000 \mathrm{~W} \cdot \mathrm{m}^{-2} \\
\text { Resolution: } 1 \mathrm{~W} \cdot \mathrm{m}^{-2} \\
\text { Accuracy: } \pm 2 \%\end{array}$ \\
\hline Water pump & PUN-EH & Circulating test water & $\begin{array}{l}\text { Rated lift: } 20 \mathrm{~m} \\
\text { Rated discharge: } 50 \mathrm{~L} \cdot \mathrm{min}^{-1} \\
\text { Maximum flow rate: } 15 \mathrm{~L} \cdot \mathrm{min}^{-1}\end{array}$ \\
\hline
\end{tabular}




\section{Test methods and principles}

According to the GB 50178-93 "Building climate zoning standards" ${ }^{[19]}$, the Wenzhou area belongs to the third area. According to the division of wind and solar energy assessment standards of the National Meteorological Administration, its solar energy resources belong to the resource utilization area, and the solar energy utilization system has a solar energy guarantee rate of more than $40 \%$. The vacuum tube solar water heating system and the air source heat pump hot water system are arranged on the roof of the experimental apartment, which comply with the standards.

\subsection{Test cycle determination}

According to the annual meteorological data collected, the meteorological data in May 2019 are as follows: (1) $21.75^{\circ} \mathrm{C} \leq$ the average outdoor environment temperature $t_{a} \leq 27.63{ }^{\circ} \mathrm{C}$; (2) $0 \mathrm{~m} \cdot \mathrm{s}^{-1}$ the average flow rate of ambient air $v_{a} \leq 1.01 \mathrm{~m} \cdot \mathrm{s}^{-1}$; (3) the solar radiation is $\mathrm{J}$ in the following interval: the number of days with $J<8$ $\mathrm{MJ} \cdot\left(\mathrm{m}^{2} \cdot \mathrm{d}\right)^{-1}$ is 7 days, the number of days with 8 $\mathrm{MJ} \cdot\left(\mathrm{m}^{2} \cdot \mathrm{d}\right)^{-1} \leq J<13 \mathrm{MJ} \cdot\left(\mathrm{m}^{2} \cdot \mathrm{d}\right)^{-1}$ is 7 days, the number of days with $13 \mathrm{MJ} \cdot\left(\mathrm{m}^{2} \cdot \mathrm{d}\right)^{-1} \leq J<18 \mathrm{MJ} \cdot\left(\mathrm{m}^{2} \cdot \mathrm{d}\right)^{-1}$ is 5 days, the number of days with $18 \mathrm{MJ} \cdot\left(\mathrm{m}^{2} \cdot \mathrm{d}\right)^{-1} \leq J$ is 12 days.

The above data are compared with the GB/T 50801-2013 "Evaluation standard for application of renewable energy in buildings"[17], which meets the requirements. Therefore, May is chosen as the test cycle for the performance study of renewable energy building energy supply system, and the system is guaranteed to operate continuously for 3 days under the condition that the average load rate is not less than $50 \%$ of the design value. The average load rate of the system is not less than $50 \%$ of the design value ${ }^{[17]}$.

\subsection{Energy consumption ratio analysis of energy supply system}

During the test period, two renewable energy buildings were 11 stories, with 6 households on each floor, with an average of 3 households per household. The heat generated by the vacuum tube solar water heating system to provide domestic hot water for the household is equivalent to that of heating water with the same volume, quality and temperature. The energy consumption per unit water consumption is defined as the energy consumption ratio of vacuum tube solar water heating system $\eta_{\text {solar. Another renewable energy building is }}$ provided by the air source heat pump hot water system to provide household hot water for the residents. Similarly, the energy consumption ratio of the air source heat pump hot water system is defined $\eta_{\text {pump. }}$. The energy consumption ratio of the solar hot water system $\eta_{\text {solar }}$ and the air source hot water system $\eta_{\text {pump }}$ was compared during the test, and the result is shown in Figure 3.

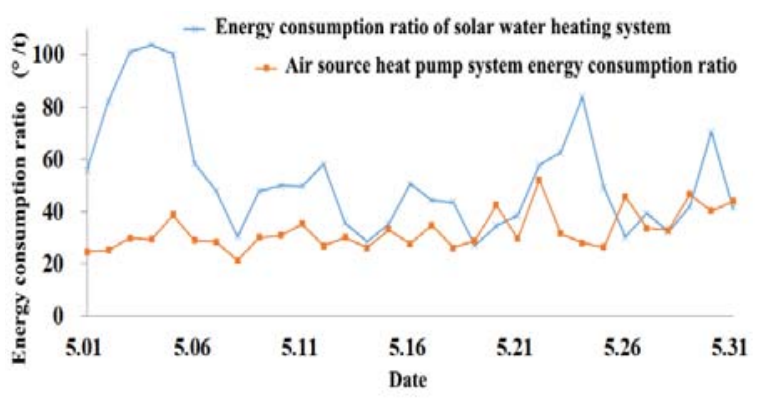

Figure3. Comparison of Energy Consumption Ratio between the Air Source Heat Pump Water System and the Compact All-Glass Vacuum Tube Solar Water Heating System

From Figure 3, we can see that during the 31 days of the test period, there are 25 days when the energy consumption of solar water heating system $\eta_{\text {solar }}$ is higher than the air source hot water system $\eta_{\text {pump }}$, and the difference of energy consumption of two kinds of renewable energy supply system is $\Delta \eta_{5.1}$ is $31.20, \Delta \eta_{5.2}$ is $87.01, \Delta \eta_{5.3}$ is $70.94, \Delta \eta_{5.4}$ is $74.47, \Delta \eta_{5.5}$ is $61.47, \Delta \eta_{5.6}$ is $29.47, \Delta \eta_{5.7}$ is $19.64, \Delta \eta_{5.8}$ is $9.14, \Delta \eta_{5.9}$ is $17.60, \Delta \eta_{5.10}$ is $19.02, \Delta \eta_{5.11}$ is $14.27, \Delta \eta_{5.12}$ is $31.29, \Delta \eta_{5.13}$ is $5.50, \Delta \eta_{5.14}$ is $72.21, \Delta \eta_{5.15}$ is $2.24, \Delta \eta_{5.16}$ is $22.94, \Delta \eta_{5.17}$ is $9.65, \Delta \eta_{5.18}$ is $17.49, \Delta \eta_{5.21}$ is $8.87, \Delta \eta_{5.22}$ is $5.56, \Delta \eta_{5.23}$ is $31.11, \Delta \eta_{5.24}$ is $55.78, \Delta \eta_{5.25}$ is $22.78, \Delta \eta_{5.27}$ is $5.55, \Delta \eta_{5.30}$ is 30.23 ; the rest time the energy consumption of the solar hot water system $\eta_{\text {solar }}$ is lower than the air source hot water system $\eta_{\text {pump }}$. The difference value of energy consumption ratio of the two renewable energy systems is $\triangle \eta 5.19$ is $-1.80, \triangle \eta 5.20$ is $-8.06, \Delta \eta_{5.26}$ is $-15.56, \Delta \eta_{5.28}$ is $\quad-0.42, \Delta \eta_{5.29}$ is $-4.78, \Delta \eta_{5.31}$ is -2.58 . And further analyzes the system performance parameters of the 6 day when the energy consumption ratio is less than zero,including temperature, radiation, sunshine hours, wind speed, inlet and outlet water temperature of solar water heating system and air source heat pump hot water system, the outlet temperature of solar hot water system $\mathrm{T}_{\text {sout, }}$ inlet temperature of solar hot water system $T_{\text {sin, }}$, the water outlet temperature of the air source heat pump hot water system $T_{\text {pout }}$ and the water inlet temperature of the air source heat pump hot water system $\mathrm{T}_{\text {pin }}$, the result is shown in Figure 4.

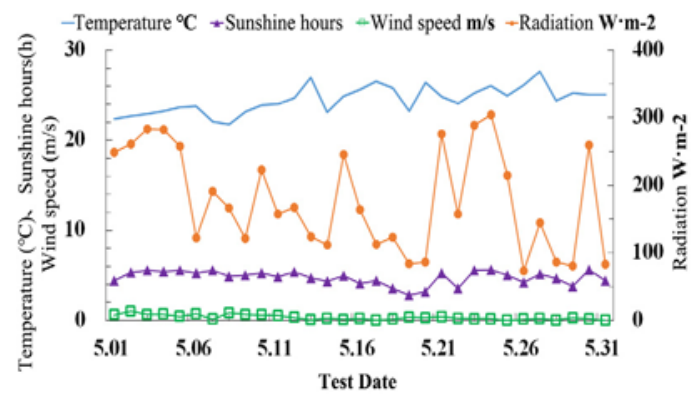

(a) meteorological data 


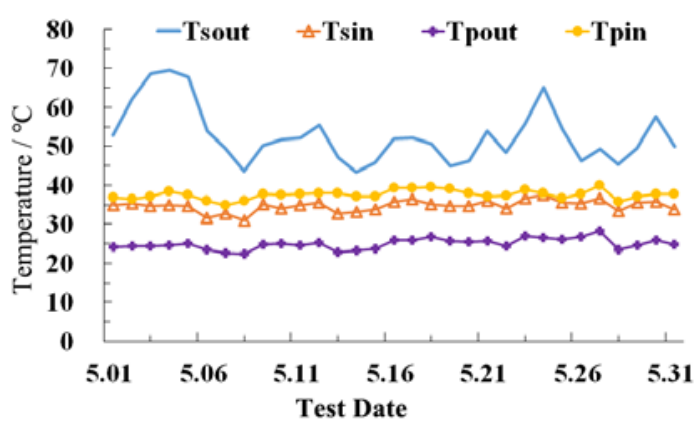

(b) inlet and outlet temperature of power supply system

Figure 4. Changes in Performance Parameters of Energy Supply Systems during the Test Period

From Figure 4, it can be concluded that the average temperature of the test period is 24.51 degrees, the average solar radiation is $177.50 \mathrm{~W} \cdot \mathrm{m}^{-2}$, the mean sunshine time is $4.76 \mathrm{~h}$, the average wind speed is 0.34 $\mathrm{m} \cdot \mathrm{s}^{-1}$; The average water outlet temperature of solar hot water system $\mathrm{T}_{\text {sout }}$ is $52.76{ }^{\circ} \mathrm{C}$, the average inlet water temperature of the solar hot water system $\mathrm{T}_{\text {sin }}$ is $34.73{ }^{\circ} \mathrm{C}$, the average outlet water temperature of the air source heat pump hot water system $\mathrm{T}_{\text {pout }}$ is $24.93{ }^{\circ} \mathrm{C}$, and the average inlet water temperature of the air source heat pump hot water system $T_{\text {pin }}$ is $37.60{ }^{\circ} \mathrm{C}$. Because $\triangle \eta_{5.19}$, $\triangle \eta_{5.20}, \triangle \eta_{5.26}, \triangle \eta_{5.28}, \triangle \eta_{5.29}$ and $\Delta \eta_{5.31}$ are negative, analysis of the six days of the weather, light rain or light rain to moderate rain, the sun radiation were $84.17 \mathrm{~W} \cdot \mathrm{m}^{-2}$, $86.33 \mathrm{~W} \cdot \mathrm{m}^{-2}, 73.17 \mathrm{~W} \cdot \mathrm{m}^{-2}, 86.29 \mathrm{~W} \cdot \mathrm{m}^{-2}, 81.08 \mathrm{~W} \cdot \mathrm{m}^{-2}$, $83.33 \mathrm{~W} \cdot \mathrm{m}^{-2}$, are lower than the monthly average of $177.5 \mathrm{~W} \cdot \mathrm{m}^{-2}$. The duration of sunshine was $2.82 \mathrm{~h}, 3.20 \mathrm{~h}$, $4.25 \mathrm{~h}, 4.63 \mathrm{~h}, 3.81 \mathrm{~h}, 4.41 \mathrm{~h}$ respectively, which were all lower than the monthly average of $4.76 \mathrm{~h}$.

Because solar radiation and sunshine duration are important performance parameters ${ }^{[20]}$ that affect the performance of solar water heating system, under the same experimental conditions, when solar radiation is low and sunshine duration is shorter, the collector efficiency and heat collection capacity of solar water heating system are relatively low, which is not enough to provide enough hot water for households. As a result, the energy consumption ratio of solar water heating system $\eta_{\text {solar }}$ in the energy supply system is lower than energy consumption ratio of air source hot water system $\eta_{\text {pump. }}$.

\section{Results and analysis}

Entropy values reflect the magnitude of useful information provided by each evaluation factor to decision making evaluation. If the entropy of a factor is smaller, the more information and weight the factor will provide, the weight of each index $C_{i j}$ of renewable energy building energy supply system can be calculated by entropy weight method. The process ${ }^{[21]}$ is as follows:

\section{(1) Data matrix}

$$
A=\left(\begin{array}{ccc}
X_{11} & \cdots & X_{1 m} \\
\vdots & \vdots & \vdots \\
X_{n 1} & \cdots & X_{n m}
\end{array}\right)_{n \times m}, \quad \mathrm{X}_{i j} \text { is the value of the } \mathrm{j} \text { index }
$$

of the first $i$ scheme.

(2) Nonnegative processing of data
The entropy method is based on the ratio of the total value of each index to the sum of the same index value. Therefore, there is no dimensional effect and no standardized processing is needed. If there is a negative number in the data, the data should be de-negated. In addition, in order to avoid the meaningless logarithm of the entropy value, data translation is needed.

For bigger and better indicators:

$$
\begin{aligned}
& X_{i j}^{\prime}=\frac{X_{i j}-\min \left(X_{1 j}, X_{2 j}, \cdots, X_{n j}\right)}{\max \left(X_{1 j}, X_{2 j}, \cdots, X_{n j}\right)-\min \left(X_{1 j}, X_{2 j}, \cdots, X_{n j}\right)}+1, \\
& i=1,2, \cdots, n ; j=1,2, \cdots, m,
\end{aligned}
$$

For smaller and better indicators:

$$
\begin{aligned}
& X_{i j}^{\prime}=\frac{\max \left(X_{1 j}, X_{2 j}, \cdots, X_{n j}\right)-X_{i j}}{\max \left(X_{1 j}, X_{2 j}, \cdots, X_{n j}\right)-\min \left(X_{1 j}, X_{2 j}, \cdots, X_{n j}\right)}+1, \\
& i=1,2, \cdots, n ; j=1,2, \cdots, m,
\end{aligned}
$$

For convenience, the data after nonnegativity are still $X_{i j}$.

(3) Calculate the proportion of the $i$-th scheme in the $j$-th index

$$
P_{i j}=\frac{X_{i j}}{\sum_{i=1}^{n} X_{i j}} \quad(j=1,2, \cdots m)
$$

(4) Calculation Entropy of No. $j$ index

$$
e_{j}=k^{*} \sum_{i=1}^{n} P_{i j} \log \left(P_{i j}\right)
$$

Among them, $\mathrm{k}>0$, ln are natural logarithms, $\mathrm{e}_{\mathrm{j}}$ is greater than or equal to 0 , constant $\mathrm{K}$ in formula is related to sample number $\mathrm{m}$, general order $k=1 / \ln m$, then $0 \leq \mathrm{e} \leq 1$.

(5) Calculation the difference coefficient of No. $j$ index

For item $\mathrm{j}$, the greater the difference between the index value $X_{i j}$ and the greater the effect of the scheme evaluation, the smaller the entropy. If $g_{j}=1-e_{j}$, the larger the $g_{j}$, the more important the index is.

(6) Seeking weights

$$
W_{j}=\frac{g_{j}}{\sum_{j=1}^{m} g_{j}}, j=1,2 \cdots m
$$

(7) Calculate the correlation function of the matter element to be evaluated

In the extension theory, correlation function is usually used to characterize the subjection degree of each target of the evaluated object on each evaluation grade, and its formula is as follows:

$$
\begin{aligned}
& k_{j}\left(x_{i}\right)=\left\{\begin{array}{c}
-\frac{\rho\left(x_{i}, x_{0 j i}\right)}{\left|x_{0 j i}\right|}, x_{i} \in x_{0 j i} \\
\frac{\rho\left(x_{i}, x_{0 j i}\right)}{\rho\left(x_{i}, x_{p i}\right)-\rho\left(x_{i}, x_{0 j i}\right)}, x_{i} \notin x_{0 j i}
\end{array}\right. \\
& \rho\left(x_{i}, x_{p i}\right)=\left|x_{i}-\frac{1}{2}\left(a_{p i}+b_{p i}\right)\right|-\frac{1}{2}\left(b_{p i}-a_{p i}\right) \\
& \left|x_{0 j i}\right|=\left|\left(a_{0 j i}-b_{0 j i}\right)\right| \\
& \rho\left(x_{i}, x_{0 j i}\right)=\left|x_{i}-\frac{1}{2}\left(a_{0 j i}+b_{0 j i}\right)\right|-\frac{1}{2}\left(b_{0 j i}-a_{0 j i}\right)
\end{aligned}
$$

In the formula, $k_{j}\left(x_{i}\right)$ is the correlation degree of the $\mathrm{i}$ 
evaluation index belonging to the $\mathrm{j}$ evaluation level; $\rho\left(x_{i}, x_{0 j i}\right)$ is the distance between point $x_{i}$ and interval $x_{p i}$; $x_{0 j i}$ is the module of the interval $x_{0 j i}=\left\langle a_{0 j i}, b_{0 j i}\right\rangle$.

(8) Determine the comprehensive correlation degree

Assuming that the weight coefficient of the $i$ evaluation index $c_{i}$ is $\omega_{i}$, the comprehensive correlation degree of multiple indexes $K_{j}(N)$ about the evaluation level $\mathrm{j}$ of the object $\mathrm{N}$ to be evaluated is:

$$
K_{i}(N)=\sum_{i=1}^{n} \omega_{i} k_{j}\left(x_{i}\right)
$$

The larger the $K_{j}(N)$ value, the higher the correlation degree between the $\mathrm{N}$ and the evaluation grade $\mathrm{J}$ is. The evaluation level corresponding to the $\max K_{j}(N)$ is the category of the object to be evaluated $\mathrm{N}$.

\section{(9) Algorithm implementation results}

Separately calculate the comprehensive weight coefficient of the performance parameters of the solar water heating system and the air source heat pump hot water system, that is, in the solar water heating system, the weight coefficient of water outlet temperature $\mathrm{W}_{\mathrm{s} 1}$, water inlet temperature $\mathrm{W}_{\mathrm{s} 2}$, air temperature $\mathrm{W}_{\mathrm{s} 3}$, solar radiation $\mathrm{W}_{\mathrm{s} 4}$ and sunshine duration $\mathrm{W}_{\mathrm{s} 5}$; in the air source heat pump hot water system, the weight coefficient of water outlet temperature $\mathrm{W}_{\mathrm{p} 1}$, water inlet temperature $\mathrm{W}_{\mathrm{p} 2}$, air temperature $\mathrm{W}_{\mathrm{p} 3}$, solar radiation $\mathrm{W}_{\mathrm{p} 4}$ and sunshine durationand $\mathrm{W}_{\mathrm{p} 5}$. And the results are shown in Table 2.

Table2. Sub-Item Comprehensive Weight Coefficient of Renewable Energy Supply System Parameters

\begin{tabular}{|c|c|c|}
\hline & $\begin{array}{c}\text { Weight } \\
\text { coefficient } \mathrm{ws}_{\mathrm{s}} \text { of } \\
\text { solar water } \\
\text { heating system } \\
\end{array}$ & $\begin{array}{l}\text { Weight coefficient } \mathrm{w}_{\mathrm{p}} \text { of } \\
\text { air source heat pump } \\
\text { water heating system }\end{array}$ \\
\hline $\begin{array}{c}\text { Effluent } \\
\text { temperature }\end{array}$ & 0.08 & 0.08 \\
\hline $\begin{array}{l}\text { Inlet } \\
\text { temperature }\end{array}$ & 0.01 & 0.01 \\
\hline $\begin{array}{c}\text { air } \\
\text { temperature }\end{array}$ & 0.02 & 0.02 \\
\hline $\begin{array}{l}\text { solar } \\
\text { radiation }\end{array}$ & 0.78 & 0.12 \\
\hline $\begin{array}{c}\text { Sunshine } \\
\text { hours }\end{array}$ & 0.78 & 0.12 \\
\hline
\end{tabular}

The calculation of the weight coefficients of the solar water heating system and the air source heat pump hot water system is calculated from table 2 .

(1) For the solar water heating system, the weight coefficient $\mathrm{W}_{\mathrm{s} 1}$ of the system effluent temperature is 0.08 , the weight coefficient $\mathrm{W}_{\mathrm{s} 2}$ of the inlet temperature is 0.01 , the weight coefficient $\mathrm{W}_{\mathrm{s} 3}$ is 0.02 , the solar radiation weight coefficient $\mathrm{W}_{\mathrm{s} 4}$ is 0.78 , the sunshine time weight coefficient $\mathrm{W}_{\mathrm{s} 5}$ is 0.12 ; for the air source heat pump hot water system, the weight coefficient $\mathrm{W}_{\mathrm{p} 1}$ of the system effluent temperature is 0.08 , the weight coefficient $\mathrm{W}_{\mathrm{p} 2}$ of the inlet temperature is 0.01 , the weight coefficient $\mathrm{W}_{\mathrm{p} 3}$ is 0.02 , the solar radiation weight coefficient $\mathrm{W}_{\mathrm{p} 4}$ is 0.78 , the sunshine time weight coefficient $\mathrm{W}_{\mathrm{p} 5}$ is 0.12 .

(2) Comparing the weight coefficients of the solar water heating system and the air source heat pump hot water system, it is concluded that the weighting coefficients of the outlet water temperature, inlet water temperature, air temperature, solar radiation and sunshine hours in the two energy supply systems are equal to each other, that is, under the experimental conditions, the performance parameters of the two energy supply systems are comparable.

The multi index comprehensive correlation degree between the solar energy hot water system and the air source heat pump hot water system is calculated. The results are shown in Table 3.

Table3. Comprehensive Relevance of Renewable Energy Supply System Parameters

\begin{tabular}{cc}
\hline $\begin{array}{c}\text { performance } \\
\text { parameter }\end{array}$ & $\begin{array}{c}\text { Multi index } \\
\text { comprehensive correlation } \\
\text { degree } \mathrm{K}_{\mathrm{j}(\mathrm{N})}\end{array}$ \\
\hline $\begin{array}{c}\text { Effluent } \\
\text { temperature } \\
\text { Inlet temperature }\end{array}$ & 2.07 \\
air temperature & 2.04 \\
solar radiation & 2.14 \\
Sunshine hours & 4.97 \\
\hline
\end{tabular}

As shown in Table 3, for the renewable energy building energy supply system, the comprehensive correlation degree $K_{j(1)}$ of the effluent temperature to the performance of the energy supply system is 2.07 , the comprehensive correlation degree $\mathrm{K}_{\mathrm{j}(2)}$ of the inlet water temperature for the energy supply system is 2.04 , the comprehensive correlation degree $K_{j(3)}$ of the air temperature for the energy supply system is 2.14 , and the comprehensive correlation degree $\mathrm{K}_{\mathrm{j}(4)}$ of solar radiation to the energy supply system is 4.97 , the comprehensive correlation degree $\mathrm{K}_{\mathrm{j}(5)}$ of sunshine duration to energy supply system performance was 3.78. Compared with the above correlation coefficient, the $\mathrm{K}_{\mathrm{j}(4)}$ of solar radiation is the largest, followed by the $K_{j(5)}$ of sunshine duration, and the $\mathrm{K}_{\mathrm{j}(1)}$ of water outlet temperature, $\mathrm{K}_{\mathrm{j}(2)}$ of water inlet temperature and $\mathrm{K}_{\mathrm{j}(3)}$ of air temperature are slightly smaller. Among them, $K_{j(1)}$ of water outlet temperature is close to $\mathrm{K}_{\mathrm{j}(2)}$ of water inlet temperature, which is 0.07 lower than $K_{j(3)}$ of air temperature. The $K_{j(4)}$ of solar radiation is the largest, which is 2.44 times of the outlet water temperature $\mathrm{K}_{\mathrm{j}(1)}$ and the inlet water temperature $\mathrm{K}_{\mathrm{j}(2)}$, and 1.19 times higher than that of the sunshine



\section{Conclusion}

(1) In the solar water heating system and the air source heat pump hot water system, the weight coefficient of the effluent temperature of the two systems is equal to 0.08 ; the weight coefficient of the inlet water temperature of the system is equal to 0.01 ; the weight coefficient of air temperature is equal to 0.02 ; the weight coefficient of solar radiation is equal to 0.78 ; the weight coefficient of sunshine hours is equal to 0.12 ; therefore, it is concluded that under the experimental conditions, the energy consumption ratio of two energy supply systems is comparable. 
(2) For the renewable energy building energy supply system, the comprehensive correlation degree $\mathrm{K}_{\mathrm{j}(1)}$ of the effluent temperature to the performance of the energy supply system is 2.07 , the comprehensive correlation degree $K_{j(2)}$ of the inlet water temperature for the energy supply system is 2.04, the comprehensive correlation degree $K_{j(3)}$ of the air temperature for the energy supply system is 2.14 , and the comprehensive correlation degree $\mathrm{K}_{\mathrm{j}(4)}$ of solar radiation to the energy supply system is 4.97 , the comprehensive correlation degree $K_{j(5)}$ of sunshine duration to energy supply system performance was 3.78 . Compared with the above correlation coefficient, the $\mathrm{K}_{\mathrm{j}(4)}$ of solar radiation is the largest, followed by the $\mathrm{K}_{\mathrm{j}(5)}$ of sunshine duration, and the $\mathrm{K}_{\mathrm{j}(1)}$ of water outlet temperature, $K_{j(2)}$ of water inlet temperature and $K_{j(3)}$ of air temperature are slightly smaller. Among them, $K_{j(1)}$ of water outlet temperature is close to $\mathrm{K}_{\mathrm{j}(2)}$ of water inlet temperature, which is 0.07 lower than $\mathrm{K}_{\mathrm{j}(3)}$ of air temperature. The $\mathrm{K}_{\mathrm{j}(4)}$ of solar radiation is the largest, which is 2.44 times of the outlet water temperature $K_{j(1)}$ and the inlet water temperature $\mathrm{K}_{\mathrm{j}(2)}$, and 1.19 times higher than that of the sunshine duration $\mathrm{K}_{\mathrm{j}(5)}$. It also explains that among the five parameters of water outlet temperature, water inlet temperature, air temperature, solar radiation and sunshine duration, when the solar radiation and sunshine duration are less than the average, the energy consumption ratio of solar water heating system $\eta_{\text {solar }}$ in the energy supply system is lower than energy consumption ratio of air source hot water system $\eta_{\text {pump}}$, while other parameters have no significant influence on the energy consumption ratio of energy supply system.

\section{References}

1. Han Bin, Gou Enjie. The Research of energy consumption monitoring consumption 2015, 14 (5):

2. Tsinghua University. Building energy use in China 2015[M]. International Energy Energy, 2015.

3. [3] Zhao Liyong, Hu Mingfu, Yang Zhenni. Solar energy utilization technology and development[J]. Energy and Environment, 2007, (4): 55-57.

4. Zhao X, Long E, Zhang Y, et al. Experimental study on heating performance of air-source heat pump with water tank for thermal energy storage $[\mathrm{J}]$. Procedia Engineering, 2017, 205: 2055-2062.

5. Lv Y, Si P, Liu J, et al. Performance of a hybrid solar photovoltaic-air source heat pump system with energy storage[J]. Energy Procedia, 2019, 158: 1311-1316.

6. Shen C, Lei Z, Wang Y, et al. A review on the current research and application of wastewater source heat pumps in China $[\mathrm{J}]$. Thermal Science and Engineering Progress, 2018, 6: 140-156.

7. Zhuang Z, Yuan F, Ye H, et al. Study on auxiliary heat sources in solar hot water system in China[J]. Energy Procedia, 2017, 142: 3-8.

8. Le Truong N, Gustavsson L. Costs and primary energy use of heating new residential areas with district heat or electric heat pumps $[\mathrm{J}]$. Energy Procedia, 2019, 158: 2031-2038.

9. Ni L, Qv D, Yao Y, et al. An experimental study on performance enhancement of a PCM based solar-assisted air source heat pump system under cooling modes[J]. Applied Thermal Engineering, 2016, 100: 434-452.

10. Kegel M, Wong S, Tamasauskas J, et al. Energy end-use and grid interaction analysis of solar assisted ground source heat pumps in Northern Canada[J]. Energy Procedia, 2016, 91: 467-476.

11. Poppi S, Bales C, Heinz A, et al. Analysis of system improvements in solar thermal and air source heat pump combisystems[J]. Applied energy, 2016, 173: 606-623.

12. Poppi S, Bales C, Haller M Y, et al. Influence of boundary conditions and component size on electricity demand in solar thermal and heat pump combisystems[J]. Applied energy, 2016, 162: 1062-1073.

13. Cai J, Ji J, Wang Y, et al. Numerical simulation and experimental validation of indirect expansion solar-assisted multi-functional heat pump[J]. Renewable Energy, 2016, 93: 280-290.

14. Wang J, Yin Z, Qi J, et al. Medium-temperature solar collectors with all-glass solar evacuated tubes[J]. Energy Procedia, 2015, 70: 126-129.

15. Hongbing $\mathrm{C}$, Yutong G, Haoyu $\mathrm{N}$, et al. Optimization and performance study of residential centralized solar domestic hot water system[J]. Energy Procedia, 2019, 158: 6431-6437.

16. Yao K, Li T, Tao H, et al. Performance evaluation of all-glass evacuated tube solar water heater with twist tape inserts using CFD[J]. Energy Procedia, 2015, 70: 332-339.

17. GB/T50801-2013, Evaluation standard for application of renewable energy in buildings $[\mathrm{S}]$.

18. GB/T 18708-2002, Test methods for thermal performance of domestic solar water heating systems $[\mathrm{S}]$.

19. GB 50178-93, Building climate zoning standards[S].

20. GB/T 18708-2002, Test methods for thermal performance of domestic solar water heating systems[S].

21. Qiu Wenhua, Xu Xiaochun. Research for the method of green construction assessment based on the theory of matter-element extension[J]. Taiyuan University of Technology, 2017. 